Short Communication http://ajol.info/index.php/ijbcs http://indexmedicus.afro.who.int

\title{
Anti-diarrhoeal effects of three Nigerian medicinal plant extracts on E.coli-induced diarrhea
}

\author{
Bright Chukwuebuka UNAEZE ${ }^{1 *}$, Cajetan Elochukwu ILO², Chukwudi EGWUATU ${ }^{3}$, \\ Ifeoma ORABUEZE ${ }^{4}$ and Ejeatuluchukwu $\mathrm{OBI}^{2}$
}

\author{
${ }^{I}$ Department of Medical Laboratory Sciences, Faculty of Health Sciences, Nnamdi Azikiwe University, PMB \\ 5001, Nnewi, Anambra State, Nigeria. \\ ${ }^{2}$ Department of Pharmacology and Therapeutics, College of Health Sciences, Nnamdi Azikiwe University, \\ PMB 5001, Nnewi, Anambra State, Nigeria. \\ ${ }^{3}$ Department of Medical Microbiology, College of Health Sciences, Nnamdi Azikiwe University, PMB 5001, \\ Nnewi, Anambra State, Nigeria. \\ ${ }^{4}$ Department of Pharmacognosy, Faculty of Pharmacy, University of Lagos, Nigeria. \\ *Correspondent author; E-mail: brighterworld2000@yahoo.com; Tel: +234-08034013222
}

\begin{abstract}
Pawpaw root (Carica papaya), Guava leaf (Psidium guajava) and Bush Mango leaf (Irvingia gabonensis) are commonly used locally to treat diarrhoea. The present study evaluated the anti-diarrhoeal effects of these plant extracts on E. coli - induced diarrhoea in albino rats. Fresh tender roots and leaves of these plants were collected, air dried, powdered and percolated in n-hexane, Methanol and aqueous solvents. Qualitative phytochemical analysis was done using different standard methods. Diarrhoea was induced with $E$ coli in albino rats using standard procedures. Qualitative phytochemical analysis confirmed the presence of various phytochemicals like saponins, alkaloids, flavonoids, cardiac glycosides, tannins, phytates, oxalates and phenols. The extracts, in a dose dependent manner, significantly protected the rats against diarrhoea induced experimentally by $E$. coli in terms of the nature of stool passage; there was no significant difference when compared with the control drug (loperamide) $(\mathrm{P}>0.05)$. Generally, methanol extract of Irvingia gabonensis was more effective at low $(100 \mathrm{ml} / \mathrm{kg})$ and high $(200 \mathrm{ml} / \mathrm{kg})$ doses. The study justifies the ethno pharmacological uses of these medicinal plants for treatments of diarrhoeal disease.
\end{abstract}

(C) 2017 International Formulae Group. All rights reserved.

Keywords: Diarrhoea, E. coli, Carica papaya, Psidium guajava, Irvingia gabonensis.

\section{INTRODUCTION}

A Medicinal plant as described by the World Health Organization (WHO), is a plant which one or more of its parts or organs contain substances that can be used for therapeutic purposes or which are precursors for the synthesis of useful drugs. They have been proven to contain physiological active ingredients which have over the years been exploited in traditional medicine for the treatment of various human and animal diseases (Adamu et al., 2006).

Scientifically in recent times, medicinal plants have been exploited and 
tested using advanced and more accurate scientific methods in the laboratory and were found to have vast arrays of secondary metabolites which range from low molecular weight to large organic compounds and they are untapped sources of pharmaceuticals (Adebayo et al., 2001).

Diarrhoea is defined as the abnormal passage of loose or liquid stools more than three times daily and/or a volume of stool greater than $200 \mathrm{~g} /$ day. Diarrhoea is a common symptom of gastrointestinal infections caused by a wide range of pathogens including bacteria, viruses and protozoa. Diarrhoea is more prevalent in the developing world largely due to the lack of safe drinking water, sanitation and hygiene, as well as poorer overall health and nutritional status.

The incidence of diarrhoeal diseases varies greatly with the seasons and a child's age. The youngest children are most Vulnerable. Incidence is highest in the first two years of life and declines as a child grows older. Mortality from diarrhoea has declined over the past two decades from an estimated 5 million deaths among children under 5 years to 1.5 million deaths in 2004 (WHO, 2004).

Carica papaya belongs to a small family Caricaceae. It is call pawpaw in English, Okwuru ezi in Igbo, Gwanda in Hausa and Ibepe or Gbebgene in Yoruba parts of Nigeria. Psidium guajava belongs to the family Myrtaceae. The French call it goyave or goyavier, Nigerians call it Guava and Igbo part of Nigeria call it Gova, Hausa call it Gwaba, Yoruba call it Gilofa. Irvingia gabonensis, belongs to the family Irvingiaceae. It is identified by various names such as bush mango, dika nut tree, Ugiri in Igbo, Goron or Biri in Hausa and Apon in Yoruba.

The variability of the phytochemical compounds of each plant may explain why traditional medicine uses the combination of both plants to increase the antioxidant activities (Koevi et al., 2015).

E.coli is the predominant facultative anaerobic of the human Colonic Flora. The organism typically colonizes the infant gastrointestinal tract within hours of life, and there after E. coli and the host derive mutual benefit. Okorondu et al. (2013) observed that the inhibitory action of the plant extracts could be attributed to the presence of the phytochemical constituents in the plant extracts such as alkaloid, flavonoid and saponin.

The objective of the study was to determine the phytochemical components of the plants and the therapeutic effect of the plant extracts in rats infected with $E$. coli.

\section{MATERIALS AND METHODS \\ Plant collection}

Psidium guajava leaf, Carica papaya root and Irvingia gabonensis leaf were collected from Lilu town in Ihiala L.G.A of Anambra State, Nigeria. The plants were identified and authenticated in the Department of botany, Nnamdi Azikiwe University, Awka Nigeria where the sample was deposited. The root of Carica papaya was cut into pieces with matcheate, then dried and spread out with the leaves of Psidium guajava and Irvingia gabonensis on a clean surface under a shade at room temperature to exclude direct sunlight in order to prevent the active constituents of the leaves and root from being degraded due to photochemical reactions. They were air dried for about eight days after which, they were observed to be dried. The dried leaves and root were gathered, and crushed with grinder. The powder was weighed using an electric weighing balance by Kern ALS 220-4. The powder was then stored in air tight bags at room temperature and used for further extraction.

\section{Preparation of plant extracts}

The ground leaves and root were prepared in three ways to get the extracts.

\section{Aqueous Extract (Maceration Method)}

Maceration method was used for aqueous extraction. Powdered leaves of Psidium guajava and Irvingia gabonensis and root of Carica papaya were used. $150 \mathrm{~g}$ of each plant were weighed and put in $375 \mathrm{ml}$ of 
distilled water and allowed to stand for $48 \mathrm{hrs}$ and then shaken for 45 mins. The extract was filtered using british standard mesh filter and first muslin cloth and concentrated by using water bath at $50{ }^{\circ} \mathrm{C}$. The extract was then transferred into a clean container and stored in the refrigerator until required for use.

\section{Organic solvent extraction by maceration} This was carried out at Pharmacognosis Department, Faculty of Pharmaceutical Sciences, Agulu. $150 \mathrm{~g}$ of the plants sample were transferred into $1000 \mathrm{ml}$ volumetric flask, and then $375 \mathrm{ml}$ of organic solvent were added. This was covered and allowed for $48 \mathrm{hrs}$ with continuous shaking, filtered and transferred to rotary evaporator for concentration. The extract was then transferred into a clean container and stored in the refrigerator until required for use.

\section{Extraction by Soxhlet method}

This method was carried out by continuously extracting a sample with a nonpolar organic solvent for about 4-6 hrs.

\section{Experimental animal and diet}

In the study, Fifty Five (55) of about 8 weeks old health rats (Rattus norvegicus) weighing 92-130 g were used. The rats were kept in standard metal cages obtained from the faculty. Controlled conditions of temperature $\left(25 \pm 20^{\circ} \mathrm{C}\right)$, relative humidity $(50 \pm 15 \%)$ and normal photoperiod (12 - 12 hrs lightdark cycle) were maintained. Free access to standard pellet and water was ensured. Acclimatization of the rats to the metal cages (4-6 rats/cage) was done for seven (7) days and maintained according to the NIH guideline for care and use of laboratory Animals (Saha et al., 2001).

\section{Organism}

Standard organism E. coli NCTC 10418 was obtained from central Public health Laboratory London.

\section{Drug}

Loperamide $(2 \mathrm{mg})$ was obtained from Pharmacy Department Nnamdi Azikiwe University Hospital, Nnewi, Anambra State, Nigeria.

\section{Phytochemical tests}

The freshly prepared extracts were subjected to a standard phytochemical screening test for various constituents using conventional protocols.

\section{E.coli- induced diarrhoea}

Three different plant extracts with three solvents were used for the study. In each of the plant extracts, cages allotted five albino rats each, two were used as negative control and positive control, and others were used as test groups. The animals were fasted for 12 hrs and weighed. From the overnight broth culture of the test organism (E. coli), standard wire loop was used to introduced $10^{8}$ cfu into each of the sterile containers containing 0.5 $\mathrm{ml}$ of sterile distilled water, then $0.1 \mathrm{ml}$ were given intragastrically to each of the test groups to induced diarrhoea. After $24 \mathrm{hrs}$, different concentrations $(100 \mathrm{mg} / \mathrm{kg}$ and 200 $\mathrm{mg} / \mathrm{kg}$ ) in volume equivalent of the plant extracts were given to the test groups, $2 \mathrm{mg}$ of loperamide was given to the positive group while the negative control group received only the vehicle $(0.5 \mathrm{ml}$ of distilled water).

\section{Statistical analysis}

The statistical method used was 2-way ANOVA and Bonferroni post-test. This was done at $\mathrm{P}<0.05$ Level of significance.

\section{RESULTS}

Table 1 shows the results of the qualitative phytochemical analysis of different plants. The result shows the presence of various bioactive compounds such as alkaloid, saponin, flavonoid, cardiac glycoside, tannin, phytate, oxolate and phenol in the plant extracts.

Table 2 shows the effect of administered aqueous, $\mathrm{n}$-hexane and methanol extracts of Carica papaya, Psidium guajava and Irvingia gabonensis in E. coli-induced diarrhoea on albino rats. From the results, methanol extract of Irvingia gabonensis had the highest protection $(80 \%)$ at high $(200 \mathrm{mg})$ and low $(100 \mathrm{mg})$ doses when compared with the control drug (loperamide), followed by aqueous extract of Irvingia gabonensis and methanol extract of Psidium guajava that had 
$80 \%$ protection only at high dose $(200 \mathrm{mg})$. There was no significant difference when compared with the control drug (loperamide) $(\mathrm{P}>0$.05). N-hexane extracts doesn't have a good protection $(40 \%)$ at low doses.

Using 2-way ANOVA, the drugs (extracts and loperamide) offer protection from $E$. coli-induced diarrhoea in albino rats. The drugs accounts for $83.44 \%$ of the total variance.

The $\mathrm{P}<0.0001$, the effect was considered extremely significant. The protection effects of the plants differ significantly and it accounts for $5.43 \%$ of the total Variance $\mathrm{P}=0.0621$.

The protective effects of loperamide 2 $\mathrm{mg}$ significantly differ from that of normal saline $(\mathrm{P}<0.001)$ but do not differ significantly from that of any of the extracts $(\mathrm{P}>0.05)$.

Table 1: Result of Phytochemicals in the plant extracts.

\begin{tabular}{lccc}
\hline Phytochemicals & $\begin{array}{c}\text { Irvingia } \\
\text { gabonensis }\end{array}$ & Carica papaya & $\begin{array}{c}\text { Psidium } \\
\text { guajava }\end{array}$ \\
\hline Flavonoid & + & + & + \\
Tannin & + & - & + \\
Saponin & + & + & + \\
Alkaloid & + & + & + \\
Cardiac glycoside & + & + & + \\
Phytate & + & - & + \\
Oxalate & + & - & - \\
Phenol & - & & + \\
\hline Key: + - Present ; - = Absent & & &
\end{tabular}

Table 2: Effects of the extracts on E.coli- induced diarrhoea in albino rats.

\begin{tabular}{|c|c|c|c|c|c|c|c|c|c|}
\hline \multirow[b]{2}{*}{$\stackrel{气}{\stackrel{\Xi}{\Xi}}$} & \multirow{2}{*}{$\frac{\frac{n}{0}}{\frac{\sigma}{\pi}}$} & \multirow{2}{*}{ 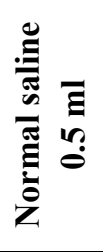 } & \multirow{2}{*}{ 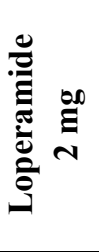 } & \multicolumn{2}{|c|}{$\begin{array}{c}\text { Aqueous } \\
\text { extract }\end{array}$} & \multicolumn{2}{|c|}{ N- hexane extract } & \multicolumn{2}{|c|}{$\begin{array}{c}\text { Methanol } \\
\text { extract }\end{array}$} \\
\hline & & & & $\begin{array}{c}100 \\
\mathrm{ml} / \mathrm{kg} \\
\text { body } \\
\text { wt. }\end{array}$ & $\begin{array}{c}200 \\
\mathrm{ml} / \mathrm{kg} \\
\text { body } \\
\text { wt. }\end{array}$ & $\begin{array}{c}100 \\
\mathrm{ml} / \mathrm{kg} \\
\text { body } \\
\text { wt. }\end{array}$ & $\begin{array}{l}200 \mathrm{ml} / \mathrm{kg} \\
\text { body wt. }\end{array}$ & $\begin{array}{c}100 \\
\mathrm{ml} / \mathrm{kg} \\
\text { body } \\
\text { wt. }\end{array}$ & $\begin{array}{c}200 \\
\mathrm{ml} / \mathrm{kg} \\
\text { body } \\
\text { wt. }\end{array}$ \\
\hline \multirow{2}{*}{ 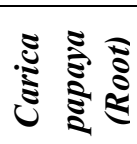 } & $\begin{array}{c}\text { Rats with } \\
\text { diarrhoea }\end{array}$ & $5 / 5$ & $1 / 5$ & $3 / 5$ & $3 / 5$ & $3 / 5$ & $2 / 5$ & $3 / 5$ & $2 / 5$ \\
\hline & Protection (\%) & 0 & 80 & 40 & 40 & 40 & 60 & 40 & 60 \\
\hline \multirow{2}{*}{ 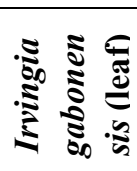 } & $\begin{array}{l}\text { Rats with } \\
\text { diarrhoea }\end{array}$ & $5 / 5$ & $1 / 5$ & $2 / 5$ & $1 / 5$ & $3 / 5$ & $2 / 5$ & $1 / 5$ & $1 / 5$ \\
\hline & Protection (\%) & 0 & 80 & 60 & 80 & 40 & 60 & 80 & 80 \\
\hline \multirow{2}{*}{ 言 } & $\begin{array}{l}\text { Rats with } \\
\text { diarrhoea }\end{array}$ & $5 / 5$ & $1 / 5$ & $3 / 5$ & $2 / 5$ & $2 / 5$ & $2 / 5$ & $2 / 5$ & $1 / 5$ \\
\hline & Protection (\%) & 0 & 80 & 40 & 60 & 60 & 60 & 60 & 80 \\
\hline
\end{tabular}




\section{DISCUSSION}

The phytochemical screening done in this work showed that Irvingia gabonensis, Carica papaya and Psidium guajava contains alkaloid, saponin, tannin, flavonoid, cardiac glycoside, phytate, oxalate and phenol. The presence of flavonoids in the extracts may make the plants to be useful in the treatment of cancer, viral, thyroid and hormonal imbalance diseases (Richa and Sharma, 2014). It has been reported by (Richa and Sharma, 2014) that flavonoids may be useful in the treatment of the above mentioned diseases. Saponins have been known to have some antihypercholesterol, hypotensive and cardiac depressant properties (Yildiz et al., 2010). Saponin also has relationship with sex hormones like oxytocin (Okwu, 2004). Oxytocin is a sex hormone involved in controlling the onset of labour in women and the subsequent release of milk (Okwu, 2004).

Alkaloids have anti-analgesic, antispasmodic, antimalaria and antibacterial properties (Stray, 1998). Tannins and Alkaloids found in these plants extract suggest that they have some antibacterial potential, most especially antimalaria and anti-diarrhoeal potentials.

The results of the study suggested that the aqueous, $n$-hexane and methanol extracts of the plants had significant anti-diarrhoeal effects. The extracts, in a dose-dependent manner, significantly protected albino rats against diarrhoea induced experimentally by E. coli in terms of severity and onsets, and the population of animals with diarrhoea.

Furthermore, loperamide which is the anti-diarrhoeal drug had $80 \%$ protection. From the result, methanol extract of Irvingia gabonensis had the highest protection $(80 \%)$ at high $(200 \mathrm{mg})$ and low $(100 \mathrm{mg})$ doses when compared with the control drug (loperamide), followed by aqueous extract of Irvingia gabonensis and methanol extract of Psidium guajava that had $80 \%$ protection only at high doses (e.g. $200 \mathrm{mg}$ ), suggesting that these plants had anti-diarrhoeal properties.

\section{Conclusion}

In conclusion, the results of this study indicated that the plant extracts had antidiarrhoeal effects.

\section{COMPETING INTERESTS}

Authors have declared that no competing interests exist.

\section{AUTHORS' CONTRIBUTIONS}

EO designed the study, wrote the protocol and wrote the first draft of the manuscript. CEI and IO managed the literature searches and supervised the work. CE managed the analyses of the work and performed the statistical analysis. BCU carried out all laboratory works.

\section{ACKNOWLEDGEMENTS}

The Authors are grateful to Anagonye Calistus of biochemistry department Nnamdi Azikiwe University Awka, Anambra State for his technical assistance.

\section{REFERENCES}

Adamu M, Fluck H, Croshaw B. 2006. Medicinal Plants and their Uses. W. Feulsham and Comp. Ltd: New York; 715.

Adebayo AO, Adewunmi CO, Essien EE. 2001. Anti-infective agent of higher plants. International Symposium of Medicinal Plants ( $5^{\text {th }}$ edn). University of Ife, Nigeria; 152-158.

Drasar BS. 1974. Hill M J. Human Intestinal Flora. Academic Press, Ltd: London, United Kingdom; 36-43.

Harborne JB. 1995. Phytochemical Methods. A Guide to Modern Techniques of Plant Analysis ( $3^{\text {rd }}$ Edn). Champman and Hall: New York. 
Koevi KKA, Millogo V, Hzounda fokou JB, Sarr A, Quedraogo GA, Bassene E. 2015. Phytochemical analysis and antioxidant activities of Combretum molle and Pericopsis laxiflora. Int. J. Biol. Chem. Sci., 9(5): 2423-2431.

Okwu DE, Okwu ME. 2004. Chemical Composition of Spondia mombin plants. J. Sustain Agric. Environ., 6: 140-147.

Okorondu SI, Akujobi CO, Okorondu JN, Anyado-Nwadike $\quad$ SO. 2013. Antimicrobial activity of the leaf extracts of Moringa oleifera and Jatropha curcas on Pathogenic bacteria. Int. J. Biol. Chem. Sci., 7(1): 195-202.

Osiagie AU. 1998. Antinutritional factors,in Nutritional quality of plant foods. Ambik press, Benin City,Nigeria.
Pearson. 1974. Pearson Chemical Analysis of Foods. General Chemical Methods $\left(8^{\text {th }}\right.$ Edn): Longman Harlow, UK; 15 - 19.

Richa SS, Sharma ML. 2014. Phytochemical investigations and anatomical study of three species of Sida. Biolife, 2(2): 622629.

Saha S, Sieghart W, Fritschy JM, Batten TFC, McWilliam PN. 2001. $\gamma$ Aminobutyric acid receptor $\left(\mathrm{GABA}_{\mathrm{A}}\right)$ Subunits in rat nucleus tractus solitarii (MTS) revealed by PCR and immunohistochemistry. Molecular and Cellular Neuroscience 17: 241-257. 